\title{
The Resilience of Adolescent Participants in Social Projects for Sport
}

\author{
Resiliência em Adolescentes Participantes de Projetos Sociais \\ Esportivos
}

Ewerton Dantas Cortês Neto (https://orcid.org/0000-0002-4511-9166) ${ }^{1}$

Maihana Maira Cruz Dantas (https://orcid.org/0000-0002-6076-8535) ${ }^{1}$

Rodrigo da Silva Maia (https://orcid.org/0000-0002-8400-058X) ${ }^{1}$

Irami Araújo Filho (https://orcid.org/0000-0003-2471-7447) ${ }^{1}$

Eulália Maria Chaves Maia (https://orcid.org/0000-0002-0354-7074) ${ }^{1}$
${ }^{1}$ Programa de PósGraduação do Centro de Ciências da Saúde, Universidade Federal do Rio Grande do Norte. Av. Gal. Gustavo Cordeiro de Farias s/n, Petrópolis. 59012570 Natal RN Brasil. ewertonsports@yahoo. com.br

\begin{abstract}
The aim of this study was to evaluate the resilience of adolescents participants and non -participants of social projects for sports relating it to their sociodemographic profile. Cross-section Study, comparative and analytical, covered 134 adolescents, from ages 12 to 17 , residing in a social zone of high vulnerability in a Northeastern Brazilian city. The data collected was obtained through structured interviews and a questionnaire/ resilience scale, developed by Wagnild and Young (1993). The descriptive and inferential statistical analysis was used, especially the Student ' $T$ ' Test for the independent samples and the chi-square test. In both cases, the statistical significance level adopted was $p<0.05$. The overall mean resilience was $110.6( \pm 15.9)$ and the participants in social projects demonstrated better resilience ( $p=$ 0.063 ), with a predominance of male gender, age group 15 to 17 years old, without health problems, parents (father/mother) self-employed, retired, pensioner or unemployed with income less than 1 minimum wage, without alcohol/cigarette and other drugs. The participants of the social projects presented a better level of resilience, even though there were several unfavorable situations and many risks presented as well.
\end{abstract}

Key words Psychological resilience, Sports, Adolescent
Resumo A pesquisa tem como objetivo avaliar a resiliência de adolescentes participantes e não participantes de projetos sociais esportivos relacionando-a ao seu perfil sociodemográfico. Estudo de corte transversal, comparativo e analítico, abrangeu 134 adolescentes, com faixa etária compreendida de 12 a 17 anos, residentes em zona de alta vulnerabilidade social de um município do nordeste brasileiro. A coleta de dados deu-se com a realização de entrevista estruturada e a aplicação do questionário/escala de resiliência desenvolvida por Wagnild e Young (1993). Utilizou-se de análise estatística descritiva e inferencial, especialmente $o$ uso do teste $T$ para amostras independentes $e$ o teste qui-quadrado. Para ambos, adotou-se um nível de significância estatística de $p<0,05$. A resiliência média geral foi $110,6( \pm 15,9)$ e os participantes de projetos sociais apresentaram melhor resiliência $(p=0,063)$, com predominio de gênero masculino, faixa etária de 15 a 17 anos, sem problemas de saúde, pais (pai/mãe) autônomos, aposentado, pensionista ou desempregado com renda menor do que 1 salário mínimo, sem uso de bebida alcoólica/cigarro e outras drogas. Os participantes de projetos sociais apresentaram melhor nível de resiliência, mesmo em diversas situações desfavoráveis, com fatores de riscos presentes.

Palavras-chave Resiliência psicológica, Esportes, Adolescente 


\section{Introduction}

The research that addresses social vulnerability in children and adolescents, under serious and profound exposures to situations of personal risk, have demonstrated the interest of contact among researchers with the populations that live in this context of social and economic inequality. The studies evaluate the environment and the response found of these subjects in the most unfavorable circumstances ${ }^{1-4}$.

A frequent aspect that permeates the daily lives of children and adolescents in situations of risk and vulnerability are the various forms of rights violation: child labor, negligence, sexual abuse and exploitation, domestic violence, among other deleterious risk factors for the individual's development. How do those subjects overcome these obstacles and become adults with no biopsychosocial prejudice? Research, in general, aims to answer how these people overcame the environmental adversity without resignifying the negative impact of the risks, especially for those in such peculiar developmental condition as explicitly defended by $(\mathrm{ECA})^{5}$, therefore, in need of protection and care of adults ${ }^{6,7}$.

Originally, from Latin, the word resilio means to return to an earlier state. Before being applied in the field of human sciences, the word was utilized by exact sciences to refer to the elastic capacity of certain materials. For purposes of this work, resilience is the ability of individuals to overcome the risk factors to which they are exposed, developing behaviors to cope with adversities, in other words, the risk factors ${ }^{8,9}$. It is understood, therefore, that resilience is a fundamental protection factor to be studied and potentialized in children and adolescents in contexts of risk, as a positive way of coping with such contexts. Three different types of protection factors are defined: individual (positive self-esteem, ability to solve problems, intelligence, self-control); family (transmitted by family members through a positive bond with caregivers); and environmental support (promoted by significant others that assume the role of safe reference to the child $)^{10,11}$.

For better comprehension of these factors, it is interesting to initiate from the understanding that in stressful circumstances, it serves as a resource that helps the individual to interact with life events and achieve good results, avoiding negative consequences. Resilience is not simply the opposite of risk. It is not synonymous with some protection factor. Resilience implies a uni- versal approach to the health and behavior of young people and is a resource to be cultivated and obtained for all adolescents ${ }^{11}$.

Standing out among the risk factors are the contexts of vulnerability, especially those related to law violations related to the poor. Endowed with a historical heritage of social injustice and possessing a large portion of the world's natural resources, Brazil ranks 75th in the Human Development Index (HDI) according to the United Nations Development Programme (UNDP) ${ }^{12}$, which characterizes it as a country of low human development. At the same time, we have a contingent of 14 million unemployed and $10.3 \%$ of the population poor. Therefore, we are a country of contrasts. The biggest victims are children and young people. They are the ones who are most vulnerable. This vulnerability enhances the chances of school dropout and failure, higher opportunities for inclusion on the drug path and criminal career, accidents and unprotected sexual activities, among many other events that are harmful to individuals ${ }^{13}$. The possible consequences of poverty can cause serious threats for the development of children and adolescents, especially because it interferes in the biopsychosocial elements of the population and can cause social deprivation, educational disadvantage, disruption of ties, among other damage to physical and mental health.

Therefore, interventions are needed for removing children and adolescents from risky situations and placing them in stimulating and educational environments. A strategy that is emerging in the fight against poverty articulating resilience and social inclusion are the Social Projects for Sport. Especially in Brazil, they have achieved great prominence, as well as being proven. In recent years, they have been enhancing the biopsychosocial aspects of their participants ${ }^{14}$. The children and adolescent participants in Social Projects for Sport demonstrate more satisfactory behavior, greater capacity for interpersonal relationships, better physical conditions, better school performance and better life quality compared to children and adolescents who do not participate in complementary actions in the Educational sport area ${ }^{2-4,13-15}$.

Into this perspective to investigate the impact caused by sports activities in adolescents, the aim of this study was to evaluate the resilience of adolescents participants and non-participants of social projects for sports relating it to their sociodemographic profile. 


\section{Methods}

Descriptive, cross-sectional and quantitative research was carried out in three public schools located in the western zone of Natal/RN. These schools were selected because they are the only schools that have a mutual cooperation agreement with the NGO Cooperation Attitude. This NGO is home to social projects for sports entitled "Projeto Celeiro" which allows students who wish to participate in sports activities. There were selected 134 adolescents, 80 male and 54 female, among the subjects of this research, 72 participants of social projects for sports (53.7\%) and 62 non-participants of social projects for sports $(46.3 \%)$.

The participants of the social projects for sports were students of the "Projeto Celeiro" of the NGO Atitude Cooperação whose objective is to foment sports practices such as soccer, indoor soccer, volleyball and judo, with the purpose of integral development of personal, social, productive and cognitive competences in adolescents, respecting the various stages of human development. The NGO Atitude Cooperação was created in 2006 with the purpose of identifying and making viable new socio-economic-cultural alternatives for communities in situations of social risk, to develop activities and socially responsible actions based on ethics, cooperative principles and aimed to improve the community quality of life.

It was conducted the sample calculation for determining the sample size based on previous studies of adolescent school social projects for sports $^{13,15}$. The $G^{\star}$ Power 3.1.3 software was used to calculate the sample size, using the effect size at $30 \%$, the $\alpha$ error at 0.05 and the power of $80 \%$ (1 - $\beta$ error).

The allocation of the adolescents in the groups of participants and non-participants of social projects for sport was performed intentionally in the three selected schools, according to the inclusion criteria: participants in social sports projects, from ages 12 to 17 , regularly enrolled in the partner schools of the NGO Atitude Cooperação for at least 6 months as part of the project; and for non-participants, under obligation, adolescents could not have participated in any social project, regardless of the area of activity. Young people who were absent during the data collection period were excluded.

Two instruments were used during the data collection: a structured interview script aimed at collecting the sociodemographic data of adolescents and their families (gender, age group, health problems, occupation and income of par- ents, use of licit and illicit drugs, among others), and the resilience scale developed by Wagnild and Young ${ }^{16}$, an instrument used to assess the resilience of adolescents and measure levels of positive psychosocial adaptation to certain life events. The Resilience Scale consists of 25 positive issues addressing "personal competence" (self-confidence, independence, determination, invincibility, control, resourcefulness and perseverance) and "acceptance of self and life" (adaptability, balance, flexibility and perspective of life) with Likert type response ranging from 1 (totally disagree) to 7 (totally agree). The scale scores range from 25 to 175 points, with high values indicating high resilience, with good reliability and validity of this instrument, already adapted to Portuguese ${ }^{17}$.

The participants were informed about the objectives of this research and had access to all necessary clarifications about the procedures adopted, so that they could choose to participate in the research, in order to accomplish all the necessary ethical aspects of this study. This research was approved by the Ethical Committee of the Hospital Universitário Onofre Lopes/ Universidade Federal do Rio Grande do Norte, in fulfillment of all requirements bidden by the Resolution No. 196/96 of the Conselho Nacional de Saúde do Brasil (Brazilian National Council), about Research Involving Human Beings.

The institutions involved (NGO Atitude Cooperação and the respective municipal and state public schools) allowed the study to be carried out, after signing the agreement of conformity for the Institution. At the time of the interview with the adolescents, the signing of the Term of Free and Informed Consent was requested and the authorization of the respective parents/ guardians.

The data gathered was typed and tabulated in Microsoft ${ }^{\mathrm{TM}}$ Excel and exported to IBM SPSS statistical software, version 20.0, in which descriptive and inferential analyzes were performed. The non-parametric Chi-square test was used to identify possible associations of sociodemographic characteristics of adolescents and parents with the variable whether or not they participated in social sports projects. The normality of the resilience variable was tested and presented a normal distribution according to the Kolmogorov-Smirnov test, using the T-Test to analyze the differences of resilience averages with the variables participation of social projects for sports and gender of the respondents. A p $<0.05$ level of statistical significance was adopted. 


\section{Results and discussions}

In an initial characterization, the western region of Natal, according to data from the Secretaria de Mobilidade Urbana do Município (SEMURB) ${ }^{18}$ is ranked at a very high social vulnerability. This implies a low quality of life index in terms of income, environment and education according to data from the Secretaria Municipal de Planejamento e Gestão Estratégica (SEMPLA) ${ }^{19}$. Such situation is very challenging because, apart from being the most violent region of the city, housing is precarious, there is a high population density, and few opportunities for personal growth, with limited access to educational, cultural and social environments. There is a high volume of children and adolescents spending a significant part of the day on the street.

In the universe researched 134 adolescents were contemplated, $59.7 \%$ male and $40.3 \%$ female, of which $53.7 \%$ of the adolescents surveyed participated in a social project. There was a predominance of males ( $\mathrm{p}$-value $=0.001$ ), age group between 12 and 14 years old, no health problems, father employed in a private company and income of up to 1 minimum wage, autonomous mothers, retired, pensioner or unemployed and income of up to 1 minimum wage, make use of alcohol/cigarettes and do not make use of other drugs, according to Table 1.

It turns out that users of social projects for sports usually come from low-income families, which shows success in the public focus. Intentionally, such actions are implemented in these places to facilitate their access, if they develop close to the community and have the participation of families. On the other hand, financial adversity is undoubtedly a constant risk factor and threat to the well-being of children and adolescents, as well as a limiting factor for development opportunities ${ }^{11,20,21}$.

Poverty brings a series of sequelae to those who suffer from it, since various spheres of their lives are affected, among them, health, education, culture, leisure, work, among others. These individual or environmental obstacles increase the vulnerability of the individual to unsatisfactory results in their development, which may lead them to trigger pathologies and emotional disturbances, situations that constitute threats to physical/psychological health ${ }^{22,23}$. With so many ills, what can the social project for sports do? What can sport do? It is not just a question of "removing from the street" 4 . In this perspective, education through sport is an important way of social inclusion, especially when it is articulated and inserted in everyday school life. Through such projects and their strategies, it is possible to enhance personal and social protection factors of those involved, as well as to provide new ones. This is what social sports projects propose: resilience.

According to Table 2, it can be observed that adolescents in general had an average resilience of $110.6( \pm 15.9)$ with significant difference $(p>$ 0.001 ). When comparing the means (DV) of the adolescents who participated $(113.0 \pm 16.8)$ to those who did not participate in the social projects $(107.8 \pm 14.5)$, the resilience was greater in the social project participants than those who did not participate, with a non-significant difference $(\mathrm{p}=0.063)$.

It is important to emphasize, in general, that sport is considered an important tool for developing the individuals' biopsychosocial aspects and minimizing the risk factors that affect one daily, especially children and adolescents. Social inclusion, positive behavioral changes, filling in free time, increasing school performance, learning sports and improving motor performance are some of the main benefits of social projects in sport. Physical sports activities can potentiate protective factors, even in the face of a very unfavorable scenario ${ }^{2,15}$.

Sport is a motivating tool for educational action to ensure protection factors, associated with the promotion of physical, social and mental well-being, self-knowledge and new friend relationships in formation, moral or social personality of its practitioners, with the possibility of activities that emphasize art and support for schooling. Studies demonstrate the importance of sports practice in the process of formation and human development of individuals, regardless of the stage of life, highlighting the physiological, psychological and social aspects, moral values and prevention of chronic-degenerative diseases, family breakdown and habits already mentioned in the study. However, it is indispensable to differentiate the real contribution of the social sportive practice from the natural processes of growth and development of individuals. The projects and programs aim to provide their contribution in search of promoting human development by creating an opportunity of permanent changes for the participants and not run the risk of encouraging the practice for only the sake of practice 4 .

When comparing the mean resilience scores with the sociodemographic characteristics of the 
Table 1. Sociodemographic characteristics of participants and non-participants in social sport projects. NatalRN, 2017.

\begin{tabular}{|c|c|c|c|c|}
\hline & & \multicolumn{2}{|c|}{ Participant of social project } & \multirow{2}{*}{$\begin{array}{c}\text { Chi-Square } \\
\text { p-value }\end{array}$} \\
\hline \multicolumn{2}{|c|}{ Sociodemographic characteristics } & $\begin{array}{c}\text { Yes } \\
\text { n (\%) }\end{array}$ & $\begin{array}{c}\text { No } \\
\text { n (\%) } \\
\end{array}$ & \\
\hline \multirow[t]{2}{*}{ Gender } & Female & $41(30,6)$ & $13(9,7)$ & 0,001 \\
\hline & Male & $21(15,7)$ & $59(44,0)$ & \\
\hline \multirow[t]{2}{*}{ Age } & 12 to 14 years & $49(36,6)$ & $58(43,3)$ & 0,827 \\
\hline & 15 to 17 years & $13(9,7)$ & $14(10,4)$ & \\
\hline \multirow[t]{2}{*}{ Health Problems } & Yes & $8(6,0)$ & $10(7,5)$ & 0,868 \\
\hline & No & $54(40,3)$ & $62(46,3)$ & \\
\hline \multirow[t]{2}{*}{ Father's main occupation } & Private Company & $30(22,4)$ & $41(30,6)$ & 0,322 \\
\hline & Self/Ret/Pens/Unem.* & $32(23,9)$ & $31(23,1)$ & \\
\hline \multirow[t]{2}{*}{ Father's income } & 1 minimum wage & $37(27,6)$ & $45(33,6)$ & 0,738 \\
\hline & $>1$ minimum wage & $25(18,7)$ & $27(20,1)$ & \\
\hline \multirow[t]{2}{*}{ Mother's main occupation } & Private Company & $20(14,9)$ & $25(18,7)$ & 0,912 \\
\hline & Self/Ret/Pens/Unem.* ${ }^{*}$ & $42(31,3)$ & $47(35,1)$ & \\
\hline \multirow[t]{2}{*}{ Mother's income } & 1 minimum wage & $52(38,8)$ & $60(44,8)$ & 0,933 \\
\hline & $>1$ minimum wage & $10(7,5)$ & $12(9,0)$ & \\
\hline Make use of Alcohol/ & Yes & $32(23,9)$ & $41(30,6)$ & 0,537 \\
\hline Cigarretes & No & $30(22,4)$ & $31(23,1)$ & \\
\hline \multirow[t]{2}{*}{ Make use of drugs } & Yes & $6(4,5)$ & $8(6,0)$ & 0,787 \\
\hline & No & $56(41,8)$ & $64(47,8)$ & \\
\hline
\end{tabular}

* Self/Ret/Pens/Unem. $=$ Self-Employed/Retired/Pensioner/Unemployed.

Table 2. Resilience comparison according to adolescents' participation in social project. Natal, 2017.

\begin{tabular}{lcccc}
\hline \multicolumn{1}{c}{$\begin{array}{c}\text { Participant of social } \\
\text { project }\end{array}$} & \multicolumn{3}{c}{ Gross value resilience } & T-Test p-value \\
\cline { 2 - 4 } & Min-Max & Average (SD) & IC 95\% & 0,063 \\
Yes & $76-156$ & $113,0(16,8)$ & $109,0-116,9$ & \\
No & $65-144$ & $107,8(14,5)$ & $104,1-111,5$ & \\
Total & $65-156$ & $110,6(15,9)$ & $107,9-113,3$ & $<0,001$ \\
\hline
\end{tabular}

respondents, a better resilience was observed in male adolescents, ages 12 to $14(\mathrm{p}=0.046)$, without health problems, self-employed parents, retired, pensioner or unemployed with income $>1$ minimum wage, without cigarette or alcohol use $(\mathrm{p}=0.045)$, as described in Table 3 .

It was verified that the means of resilience have the same socio-demographic characteristics whether or not they participated in social projects, and it was observed that in all aspects, resilience was better in the social projects participants, with a predominance of the male sex, ages 15 to 17 ( $p=0.024)$, with no health problems, parents autonomous, retired, pensioner or unemployed with income $>1$ minimum wage, without alcohol/cigarette use and other drugs (Table 3).
Admittedly this being a time of physical, biological and psychological transitions, experimentation and adoption of various behaviors (sexual, smoking, alcohol and/or drug experimentation) often occur in this age group. The changes in this period are linked to the learning of sociability, gender models, values and morals ${ }^{24}$. This is also a phase of development in which peer interaction plays a fundamental role of social support, especially in contexts of vulnerability, when the family often cannot alone provide such a role. Hence, interaction spaces that facilitate the coexistence in group, secondary socialization processes, strengthening family and community ties, such as the case of social projects, are powerful protective factors, especially to promote healthy habits and quality of life in public. 


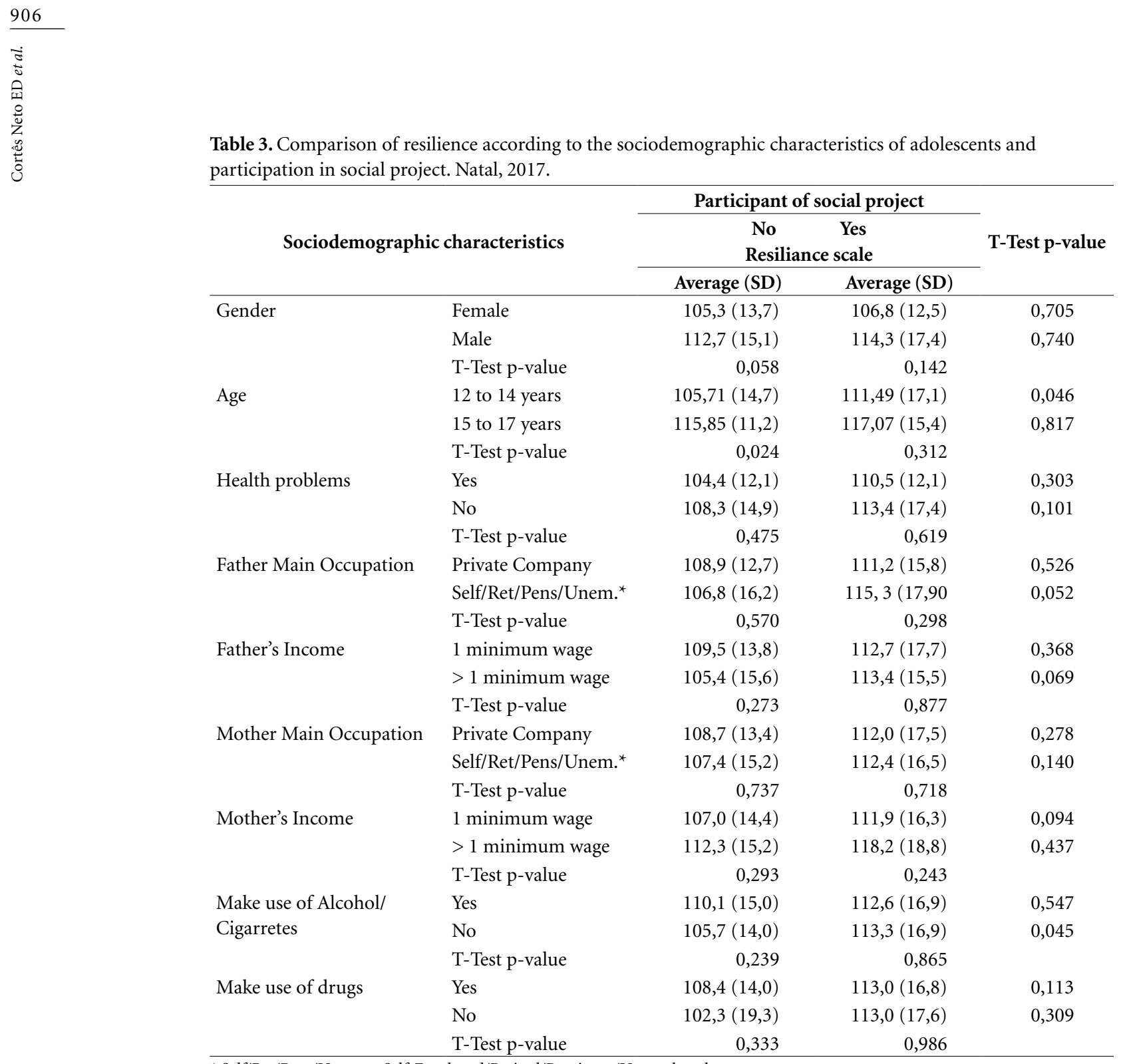

* Self/Ret/Pens/Unem. $=$ Self-Employed/Retired/Pensioner/Unemployed.

\section{Final considerations}

From the results of the study it was possible to verify that the participation in social sports projects can make adolescents more resilient. In this way, the socio-educational potential of sports in the development process of the human dimensions is also observed. This demonstrates that, in fact, some factors related to resilience are potentiated when associated with the participation of the individuals in sports activities. The literature points out to social support, interaction between peers, having a group of friends and the feeling of belonging to it are important protection factors and the same are the main principles of organized sports activities.
The relation between resilience and the participation of adolescents from ages 12 to 14 years, male gender ( $p$-value $=0.001$ ), in social projects for sport develops protection factors and coping with social vulnerabilities. Adolescents in general had a mean resilience of $110.6( \pm 15.9)$ with a significant difference $(\mathrm{p}>0.001)$, the resilience was higher in the participants of the social project than those who did not participate, without significant difference $(p=0.063)$. Even in several unfavorable situations, with risk factors present, it is possible to develop resilience.

With regard to sports as a protective factor, its association with psychological well-being is emphasized. Its inclusive, cooperative and leisure features provide a sense of control, a sense of 
competence and self-efficacy, and provide positive social interactions, self-concept and self-esteem, thus composing another element of coping with adversity and strengthening self-esteem, which contributes to the resilience.

It can be concluded that sports practice in the first decades of life may be associated with a better behavioral profile in the adult age compared to non-athletes. In addition, the frequency analysis showed that most subjects with low resilience profile were included in the non-athlete group. Thus, in realizing a reflection on the theme of resilience in the context of sports, especially in a society that has many difficulties of social order, it is possible to understand that despite this universe present obstacles to overcome constantly, it also offers the possibility to the practaiser to develop resources that will help you deal not only with these adversities, but with the many circumstances in his life.

Finally, the theme does not end with this research, because our proposal was to subsidize the members involved with social projects for sport with new knowledge and that they generate new research. In this way, we hope that this study will stimulate projects committed to human development and reduction of the social vulnerabilities.

\section{Collaborations}

ED Cortês Neto worked on the research, methodology, data and final editing. MMC Dantas worked on the research and methodology. RS Maia worked on data collect and processing of data. I Araújo Filho worked on final editing. EMC Maia worked on the research, methodology and final editing. 


\section{References}

1. Garcia I. Vulnerabilidade e resiliência. Adolesc Latinoam 2001; 2(3):128-130.

2. Santos APM, Rosa Neto F, Pimenta RA. Avaliação das habilidades motoras de crianças participantes de projetos sociais/esportivos. Motricidade 2013; 9(2):50-60.

3. Bezerra A, Domingues T, Ribeiro CHV. Esporte e inclusão social; estudo de caso de uma equipe de alto nível de futsal. Salusvita 2012;31(1):7-18.

4. Hirama LK, Montagner PC. Algo para além de tirar da rua: o ensino do esporte em projeto socioeducativo. Rev Bras Cien Esporte 2012; 34(1):149-64.

5. Brasil. Lei no 8.069, de 13 de julho de 1990. Dispões sobre o Estatuto da Criança e do Adolescente e dá outras providêcias. Diário Oficial da União 1990; 16 jul.

6. Cecconello AM. Resiliência e vulnerabilidade em famílias em situação de risco [tese não publicada]. Porto Alegre: Universidade Federal do Rio Grande do Sul 2003.

7. Prati LE, Paula Couto MCP, Koller SH. Famílias em vulnerabilidade social: Rastreamento de termos utilizados por terapeutas de família. Psicol Teoria Pesquisa 2009; 25(3):403-408.

8. Junqueira MFPS, Deslandes SF. Resiliência e maustratos à criança. Cad Saude Publica 2003, 19(1):227235.

9. Brooks R. Children at risk: fostering resilience and hope. Am J Orthopsychiatry 1994; 64(4):545-553.

10. Emery RE, Forehand R. Parental divorce and children's well-being: A focus on resilience. In: Haggerty RJ, Sherrod LR, Garmezy N, Rutter M, organizers. Stress, risk and resilience in children and adolescentes. Processes, mechanisms and interventions. Cambridge: Cambrigde University Press; 1996. p. 64-100.

11. Hutz CS, Koller SH, Bandeira DR. Resiliência e vulnerabilidade em crianças em situação de risco. Coletânias ANPEPP 1996; 1(12):79-86.

12. Programa das Nações Unidas para o Desenvolvimento (PNUD). Organização das Nações Unidas (ONU). Atlas do desenvolvimento humano no Brasil [página na Internet]. Brasília: ONU; 2017. [acessado $2017 \mathrm{Mar}$ 3]. Disponível em: http://www.pnud.org.br/atlas/

13. Cortês Neto ED, Alchieri JC, Miranda HF, Dantas-Cavalcanti FI. Elaboração de indicadores de sucesso em programas de saúde pública com foco sócio-esportivo. Rev Salud Publica 2010; 12(2):208-219.

14. Hassenpflug WN. Educação pelo esporte: educação para o desenvolvimento humano pelo esporte. São Paulo: Saraiva; 2004.
15. Cortês Neto ED, Dantas MMC, Maia EMC. Benefícios dos projetos sociais esportivos em crianças e adolescentes. Saude Transf Social 2015; 6(3):109-117.

16. Wagnild GM, Young HM. Development and psychometric evaluation of resilience scale. J Nurs Meas 1993; 1(2):165-178.

17. Pesce RP, Assis SG, Avanci JQ, Santos NC, Malaquias JV, Oliveira RVC. Adaptação transcultural, confiabilidade e validade da escala de resiliência. Cad Saude Publica 2005; 21(2):436-448.

18. Brasil. Prefeitura Municipal de Natal. Secretaria Municipal de Meio Ambiente e Urbanismo. Manual de arborização urbana de Natal. Natal: SEMURB; 2009.

19. Brasil. Prefeitura Municipal de Natal. Secretaria Municipal de Planejamento e Gestão Estratégica. Mapeando a qualidade de vida em Natal. Natal: SEMPLA; 2003.

20. Nunes T. O ambiente da criança. Cad Pesquisa 1994; 89:5-23.

21. Pierre RG, Layzer JI. Improving the life chances of children in poverty: assumptions and what we have learned. Social Policy Report 1998; 12(4):1-28.

22. Hutz CS, Koller SH. Questões sobre o desenvolvimento de crianças em situação de rua. Estud Psicol 1997; 2:175-197.

23. Zimmernman MA, Arunkumar R. Reiliency research: implications for schools and policy. Social Policy Report 1994; 8(1):1-18.

24. Aquino EML, Heilborn ML, Knauth D, Bozon M, Almeida MC, Araujo J, Menezes G. Adolescência e reprodução no Brasil: a heterogeneidade dos perfis sociais. Cad Saude Publica 2003; 19(2):377-388.

Article submitted 06/02/2018

Approved 23/07/2018

Final version submitted 25/07/2018 